\title{
Hidrolis Kulit Buah Kopi Oleh Kapang Pestalotiopsis sp. VM 9 Serta Pemanfaatan Hidrolisatnya Sebagai Medium Produksi Protein Sel Tunggal Saccharomyces cerevisiae \\ (Hydrolysis Coffea Pulp Using Extracelluler Enzymes of Pestalotiopsis sp. VM 9 and Utilization of Protein Hydrolysis For Medium Production Single Cell Saccharomyces cerevisiae)
}

\author{
Zunairoh Nidaan Khofiya, Rudju Winarsa, Kahar Muzakhar \\ Jurusan Biologi, Fakultas Matematika dan Ilmu Pengetahuan Alam, Universitas Jember (UNEJ) \\ Jln. Kalimantan 37, Jember 68121 \\ E-mail:kaharmzk@unej.ac.id
}

\begin{abstract}
Abstrak
Hidrolisis limbah kulit buah kopi oleh enzim ekstraseluler Pestalotiopsis sp. VM 9 telah dilakukan. Hasil hidrolisis menunjukkan bahwa dalam hidrolisat mengandung gula reduksi 392,35 $\mu \mathrm{g} / \mathrm{ml}$ setelah masa inkubasi hari ke-6. Analisis lanjutan menunjukkan bahwa hidrolisat dapat digunakan sebagai medium pertumbuhan Protein Sel Tunggal (PST) $S$. cerevisiae dengan tingkat pertumbuhan hingga mencapai kepadatan sel $8,5 \times 10^{6} \mathrm{sel} / \mathrm{ml}$ selama 72 jam kultivasi. Selama pertumbuhannya $S$. cerevisiae terbukti mengkonsumsi sumber karbon dari gula reduksi sebanyak $211,91 \mu \mathrm{g} / \mathrm{ml}$.
\end{abstract}

Kata Kunci: Kulit buah kopi, hidrolisis, produksi PST, Pestalotiopsis sp.

\begin{abstract}
Hydrolysis of coffee pulp waste by extracellular enzyme of Pestalotiopsis sp. VM 9 has been done. The results showed that in

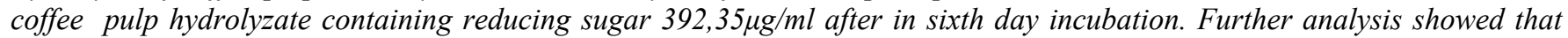
hydrolyzate can be used as a growth medium of Saccharomyces cerevisiae single cell protein (SCP) with density up to 8.5x106 $\mathrm{cell} / \mathrm{ml}$ in 72 hours of cultivation. During the growth of $S$. cerevisiae proven to consume carbon source from sugar reduction as much as $211,91 \mu \mathrm{g} / \mathrm{ml}$.
\end{abstract}

Keywords: Coffea pulp, hydrolysis, SCP Production, Pestalotiopsis sp.

\section{PENDAHULUAN}

Kopi adalah salah satu tanaman yang dibudidayakan sebagai ladang penghasilan masyarakat Indonesia. Selain itu, kopi berperan sebagai sumber pendapatan devisa negara. Produksi kopi yang tinggi menjadi penyebab meningkatnya limbah kulit kopi. Pada banyak penelitian yang telah dilakukan bahwa limbah kulit kopi dapat dimanfaatkan sebagai bioethanol [5], bahan bakar pengganti dalam bentuk briket [9], dimanfaatkan sebagai amelioran tanah alam [15].

Senyawa yang terkandung dalam kulit buah kopi yaitu $0,98 \%$ hemiselulosa, $18,65 \%$ selulosa, dan $12,25 \%$ lignin [13]. Senyawa tersebut dapat didekomposisi mikroorganisme baik bakteri maupun kapang karena limbah kulit kopi merupakan bahan organik. Agen dekomposisi yang paling efektif adalah dari golongan kapang [11]. Golongan kapang dapat mendekomposisi kandungan selulosa, hemiselulosa dan lignin pada limbah organik [16].

Salah satu jenis kapang yang dapat merombak limbah organik yang mengandung lignoselulosa adalah Pestalotiopsis sp. Karakteristik morfologi dari Pestalotiopsis sp. yang diinokulasikan pada media PDA akan terlihat seperti kapas warna putih pada awalnya dan kemudian akan muncul bintik-bintik warna hitam pada permukaan dan akan semakin gelap [6]. Pestalotiopsis sp. dapat menghasilkan enzim seperti laccase, selulase [21], dan tannase [17]. Selulase merupakan enzim yang sangat penting peranannya dalam proses biokonversi limbah-limbah organik berselulosa menjadi glukosa, makanan ternak dan etanol [10].
Hasil hidrolisis dari kulit buah kopi dapat digunakan sebagi medium pertumbuhan protein sel tunggal. Saccharomyces cerevisiae adalah golongan yeast dan salah satu Protein Sel Tunggal (PST) yang telah lama dikembangkan. Banyak penelitian tentang yeast yang sedang dikembangkan. Golongan yeast termasuk mikrobia yang memiliki pertumbuhan cepat dan dapat tumbuh pada berbagai substrat atau dengan kata lain memiliki cakupan yang luas dan dari segi nilai gizi meliputi energi, protein dan dari kesetimbangan asam amino [1].

\section{METODE PENELITIAN}

\section{Tempat dan Waktu Penelitian}

Penelitian dilaksanakan di Laboratorium Mikrobiologi, Fakultas Matematika dan Ilmu Pengetahuan Alam Universitas Jember. Waktu pelaksanaan penelitian dimulai pada bulan Januari 2018 sampai Mei 2018.

\section{Alat dan Bahan}

Alat- alat yang digunakan dalam pelaksanaan penelitian ini terdiri dari alat pembuatan media, alat standart sterilisasi, colony counter, haemocytometer tipe neubauer improve, inkubator, laminar air flow (LAF), mikroskop, mesin pencacah, pipet ukur, pipet mikro, $\mathrm{pH}$ meter, sentrifugator, spektofotometer, vortex.

Bahan yang digunakan adalah kulit buah kopi Robusta, stok kapang biakan Pestalotiopsis sp. VM 9 yang diperoleh dari hasil penelitian Yuniar (2013), stok isolat biakan Saccharomyces cerevisiae dari Balai Pengkajian dan 
Penerapan Teknologi (BPPT) Tanggerang Selatan, media PDA (Potato Dextrose Agar), media YEPD (Yeast Extract Peptone Dextrose) agar dan broth, $\mathrm{NaCl} 1 \%$, subtrat alkali ekstrak kulit lunak buah kopi, buffer phosphat, buffer asetat, akuades, alkohol 70\%, akuades $90 \%$, reagen Somogyi dan Nelson dan larutan $\mathrm{NaOH} 2 \mathrm{M}$.

\section{Persiapan Penelitian}

Pertama yaitu persiapan sampel kulit lunak buah kopi dengan cara mengeringkan sampel pada kondisi kadar air kurang dari $1 \%$, kemudian dihaluskan dengan mesin penggiling dan disimpan.

Kedua Peremajaan isolat Pestalotiopsis sp. VM9 yaitu menginokulasikan 1 ose biakan Pestalotiopsis sp. pada median PDA miring dan diinkubasi pada suhu $30^{\circ} \mathrm{C}$ selama 3 hari. Selanjutnya pembuatan subkultur $S$. cerevisisae dengan menginokulasikan 1 ose biakan $S$. cerevisiae pada media YEPD miring dan diinkubasi pada suhu $30^{\circ} \mathrm{C}$ selama 3 hari.

Ketiga, pembuatan alkali ekstrak kulit lunak buah kopi adalah mencampurkan 200 gram bubuk kulit lunak buah kopi dalam 160 gram $\mathrm{NaOH} 2 \mathrm{M}$ dan dilarutkan dalam akuades $1000 \mathrm{ml}$. Campuran tersebut dihomogenkan menggunakan magnetic stir selama 24 jam. Setelah itu dilakukan pengecekan $\mathrm{pH}$ dengan tujuan didapatkan $\mathrm{pH}$ netral atau 7 yaitu dengan penambahan asam asetat sedikit demi sedikit. Hasil hidrolisis difiltrasi menggunakan kertas saring sehingga didapatkan filtrat. Selanjutnya, filtrat diekstraksi menggunakan etanol dengan perbandingan etanol dan filtrat adalah $6: 4$. Hasil dari campuran tersebut disentrifugasi sehingga didapatkan pellet dan supernatant. Supernatant dibuang dan diambil pelletnya saja, kemudian dioven pada suhu $50^{\circ} \mathrm{C}$ selama 24 jam. Ekstrak alkali masih dalam bentuk padatan keras setelah dioven sehingga harus dihaluskan terlebih dahulu agar dapat digunakan dalam penelitian.

Keempat, pembuatan medium protein sel tunggal berbasis kulit buah kopi, ditentukan terlebih dahulu kadar air kulit buah kopi. Kulit buah kopi sebanyak 5 gram dimasukkan kedalam kantong teh dan direndam dalam akuades selama 30 menit. Kantong tersebut digantung hingga air tidak menetes, kemudian ditimbang untuk mengetahui berat basahnya. Selanjutnya dioven pada suhu $50^{\circ} \mathrm{C}$ selama 6 jam dan ditimbang, dilanjutkan dengan dioven kembali pada suhu $50^{\circ} \mathrm{C}$ selama 6 jam dan ditimbang kembali, sampai hasil yang didapatkan konstan untuk mengetahui berat kering. Hasil selisih dari berat basah dikurangi berat kering merupakan kadar air kulit buah kopi.

Tahap selanjutnya, hasil dari penentuan kadar air tersebut digunakan untuk membuat substrat kulit buah kopi jenuh air. Subtrat kulit buah kopi sebanyak 50 gram dimasukkan kedalam Erlenmeyer $500 \mathrm{ml}$ kemudian ditambahkan air sesuai kadar air yang telah dihitung. Kemudian disterilisasi pada substrat tersebut menggunakan autoklaf pada suhu $121^{\circ} \mathrm{C}$ selama 20 menit.

\section{Optimasi Hidrolisis Kulit Buah Kopi oleh Kapang Pestalotiopsis sp. VM 9}

Optimasi hidrolisis dengan cara menginokulasi $1 \mathrm{ml}$ suspensi isolat Pestalotiopsis sp. VM 9 yang telah diencerkam dalam $10 \mathrm{ml}$ akuades steril yang telah diinkubasi sesuai waktu inkubasi kepadatan spora pada medium 10 gram subtrat kulit buah kopi. Selanjutnya diinkubasi pada suhu $30^{\circ} \mathrm{C}$ selama 7 hari dan dilakukan pemanenan gula reduksi setiap harinya dimulai hari ke- 1 hingga hari ke- 7 . Hasil hidrolisis dianalisis gula reduksi menggunakan Somogyi-Nelson. Hasil analisis yang diperoleh dibandingkan dengan kurva standart glukosa yang telah dibuat sebelumnya.

\section{Hidrolisis Kulit Buah Kopi oleh Kapang Pestalotiopsis sp. VM 9}

Kapang Pestalotiopsis sp. VM 9 diinokulasi pada media substrat kulit buah kopi jenuh air steril sebanyak 50 gram diinokulasikan dengan kapang Pestalotiopsis sp. VM 9. Selanjutnya diinkubasi pada suhu $37^{\circ} \mathrm{C}$ sesuai dengan waktu inkubasi terbaik yang telah dilakukan pada optimasi hidrolisis kulit buah kopi sebelumnya, selanjutnya disterilkan menggunakan autoclave dan dilakukan pemanenan hidrolisat.

Pemanenan hidrolisat dilakukan dengan menambahkan akuades kedalam hidrolisat dengan perbandingan hidrolisat dan akuades adalah 1:4, kemudian ditambah $\mathrm{NaCl} 1 \%$ dan NaAcide $0,01 \%$ dan dishaker selama 12 jam pada suhu ruang. Selanjutnya dilakukan filtrasi menggunakan kaca Buchner filter corong sehingga diperoleh hidrolisat. Hidrolisat disentrifugasi dengan kecepatan 4000 rpm selama 10 menit untuk memisahkan filtrat dari pelletnya, dan difilter kembali menggunakan minipore filter. Setelah pemanenan kembali dilakukan uji dengan metode SomogyiNelson untuk mengetahui total gula reduksi pada produksi 50 gram kulit buah kopi.

\section{Produksi S. cereviceae Pada Media Hidrolisat Kulit Buah Kopi}

Isolat $S$. cerevisiae sebanyak 1 ose diinokulasikan pada $20 \mathrm{ml}$ media YEPD cair dan kemudian dishaker $120 \mathrm{rpm}$, selama 3 hari. Sebanyak $100 \mu$ l dari kultur tersebut diinokulasikan pada hidrolisat kulit buah kopi dengan variasi konsentrasi yaitu $0 \mathrm{x}, 2 \mathrm{x}, 3 \mathrm{x}, 4 \mathrm{x}$, dan $5 \mathrm{x}$ pengenceran dengan 2 kali ulangan dan sudah disterilisasi. Kultur $S$. cerevisiae pada hidrolisat kulit buah kopi diinkubasi shaker $120 \mathrm{rmp}, 72$ jam. Setiap interval 6 jam diambil sebanyak $500 \mu \mathrm{l}$ yang digunakan untuk mengukur jumlah sel dan konsumsi gula reduksi dari hidrolisat. Pengukuran jumlah sel menggunakan analisis spektrofotometer dengan panjang gelombang $600 \mathrm{~nm}$. Jumlah populasi PST dihitung menggunakan persamaan yang didapatkan pada pembuatan kurva standart hubungan $S$. cereviceae.

Perhitungan sisa gula reduksi dilakuakn dengan cara kultur S. cerevisiae pada variasi konsentrasi dan interval jam disentrifugasi $10.000 \mathrm{rpm}$ selama 5 menit sehingga didapatkan filtrat. Kemudian dari $50 \mu \mathrm{l}$ filtrat tersebut diuji mengguanakn metode Somogyi- Nelson dan diukur nilai absorbansinya menggunakan spektrofotometer pada panjang gelombang $500 \mathrm{~nm}$. Data absorbansi diplot pada persamaan regresi linear yang diperoleh dari kurva standart glukosa yang nantinya dibandingkan dengan larutan standart glukosa.

\section{HASIL DAN PEMBAHASAN}

\section{Optimasi Produksi Enzim}

Hasil optimasi produksi enzim pada metode SomogyiNelson menunjukkan bahwa produksi gula reduksi terbesar pada hari ke-6 inkubasi dengan angka $88,33 \mu \mathrm{g} / \mathrm{ml}$. Gula reduksi yang tinggi pada inkubasi hari ke- 6 menunjukkan bahwa aktivitas enzim esktraseluler yang dihasilkan oleh 
Pestalotiopsis sp. VM 9 paling tinggi terjadi pada inkubasi hari tersebut. Aktivitas enzim mengalami kenaikan seiring bertambahnya waktu inkubasi dari hari ke-1 hingga paling tinggi pada hari ke-6 dan mengalami penurunan aktivitas setelahnya. Hal ini dikarenakan produk enzim telah menumpuk sedangkan jumlah substrat telah semakin berkurang sehingga laju reaksi enzim menurun [12]. Pada penelitian sebelumnya [18], bahwa enzim diperoleh secara optimum oleh Pestalotiopsis sp. VM 9 pada media CMC 1\% adalah inkubasi hari ke-5. Perbedaan waktu optimum enzim dikarenakan perbedaan substrat yang harus dipecah oleh fungi. Kondisi yang mempengaruhi aktivitas enzim adalah konsentrasi substrat, konsentrasi enzim, $\mathrm{pH}$ dan suhu [12].

\section{Hasil Hidrolisis Kulit Buah Kopi oleh Pestalotiopsis sp. VM 9}

Berdasarkan jumlah gula reduksi yang diperoleh pada hari ke- 6 adalah 392,35 $\mu \mathrm{g} / \mathrm{ml}$. Gula reduksi mengandung monosakarida, beberapa oligosakarida dan beberapa polimer glukosa lainnya [4]. Pada tahap hidrolisis peran mikroba selulolitik adalah menghasilkan enzim untuk merombak atau menghidrolisis selulosa. Hidrolisis selulosa melibatkan 3 enzim selulase, yaitu (1) endo-1,4- $\beta$-D-glukanase yang bekerja secara acak sepanjang rantai selulosa menghasilkan situs baru untuk selobiohidrolase, (2) ekso-1,4- $\beta$-D-glukan yang bekerja sebagai eksoglukanase melepas selobiosa sebagai produk utama, dan (3) 1,4- $\beta$-D-glukosidase yang menghidrolisis selobiosa menjadi glukosa [8].

\section{Produksi S. cerevisiae Pada Medium Hidrolisat Kulit Buah Kopi}

S. cerevisiae ditumbuhan pada media hidrolisat kulit buah kopi yang telah dihidrolisis oleh Pestalotiopsis sp. VM 9. Hasil dari optimasi waktu inkubasi selama 72 jam dan konsentrasi pada medium hidrolisat kulit buah kopi dan diuji menggunakan spektrofotometer menunjukkan jumlah sel paling tinggi pada waktu inkubasi jam ke-54 (Gambar.1).

Pada penelitian ini terlihat bahwa $S$. cerevisiae memiliki 4 tahap fase pertumbuhan yaitu fase lag, fase log, fase stationer dan terakhir adalah fase kematian sel. Keempat fase tersebut dapat dilihat pada konsentrasi tanpa pengenceran, konsentrasi $2 \mathrm{x}$ pengenceran, dan konsentrasi $3 \mathrm{x}$ pengenceran. Sedangkan pada konsentrasi 4x pengenceran dan konsentrasi $5 \mathrm{x}$ pengenceran tidak sesuai dengan keempat fase tersebut dikarenakan konsentrasi hidrolisat lebih sedikit sehingga mempengaruhi pertumbuhan $S$. cerevisiae dimana hidrolisat adalah sumber nutrisi untuk pertumbuhan.

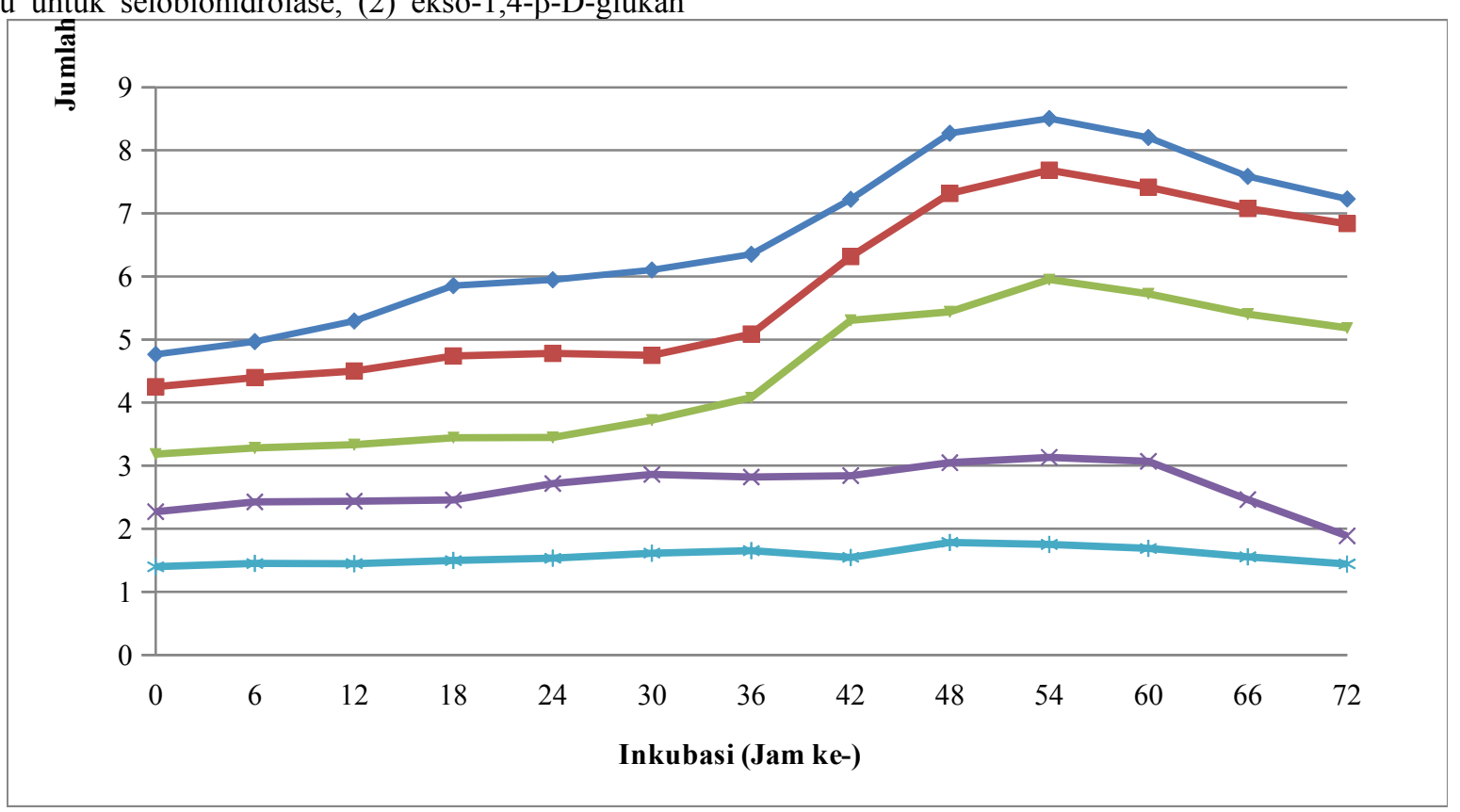

Gambar 1. Kurva Optimasi Waktu dan Konsentrasi Pertumbuhan PST S. cerevisiae Pada Hidrolisat Kulit Buah Kopi. Keterangan: $\square$ tanpa pengenceran; pengenceran $2 \mathrm{x}$; pengenceran $3 \mathrm{x}$; $\square$ pengenceran $4 \mathrm{x}$ pengenceran $5 \mathrm{x}$.

Pada konsentrasi tanpa pengenceran, konsentrasi $2 \mathrm{x}$ pengenceran dan konsentrasi $3 \mathrm{x}$ pengenceran diketahui fase log pada jam ke-0 hingga jam ke-12 dimana pada fase tersebut tidak ada pertumbuhan sel secara signifikan dikarenakan sel tersebut sedang dalam fase penyesuaian diri terhadap lingkungan (substrat) [7]. Fase lag ditunjukkan pada pertumbuhan sel pada jam ke-18 hingga jam ke- 42. Pada fase ini sel mengalami pertumbuhan secara signifikan karena sel telah mampu beradaptasi dengan medium (hidrolisat kulit buah kopi) dan mampu memanfaatkan gula reduksi. Pertumbuhan $S$. ceresvisiae pada fase stationer ditunjukkan pada jam ke-
48 hingga jam ke-60 . Pada fase stationer $S$. cerevisiae menunjukkan tidak ada lagi pertumbuhan sel secara signifikan karena konsumsi gula reduksi pada medium hidrolisat kulit buah kopi telah optimum [7]. Pada jam ke-66 hingga jam ke-72 sel mulai mengalami penurunan jumlah dan disebut fase kematian sel. Hal ini dikarenakan kandungan gula reduksi sudah mulai habis sehingga sudah tidak ada lagi gula reduksi yang dapat dipecah oleh sel dan dimanfaatkan untuk pertumbuhan sel. Selain gula reduksi, unsur lain yang diperlukan dalam pertumbuhan $S$. cerevisiae adalah magnesium, phosfor, nitrogen, karbon, hidrogen, oksigen[2] 
Pertumbuhan optimum S. cerevisiae pada medium hidolisat kulit buah kopi diikuti oleh penurunan gula reduksi (Gambar.2). Gula reduksi semakin menurun hingga jam terkahir inkubasi meskipun pada kurva pertumbuhan $S$. cerevisiae telah melewati fase stasioner yaitu fase kematian sel. Hal ini dikarenakan pada fase tersebut sel tetap hidup meski tidak menunjukkan tanda pertumbuhan, akan tetapi sel tetap membutuhkan nutrisi untuk hidup. Sehingga gula reduksi tetap mengalami penurunan. Selain itu dimungkinkan bahwa pada awal pertumbuhan hingga memasuki fase stasioner $S$. cerevisiae cenderung memanfaatkan gula sederhana seperti glukosa dan fruktosa [3]. Karena jumlah gula sederhana menurun dimungkinkan yang tersisa adalah gula jenis polisakarida dan sulit dipecah oleh $S$. cerevisiae sehingga mempengaruhi metabolisme sel. Hal tersebut memunginkan dapat memperlambat laju pertumbuhan $S$. cerevisiae dan akhirnya masuk pada fase kematian sel.

Pada perlakuan tanpa pengenceran sisa gula reduksi pada jam inkubasi ke-72 adalah 180,44 $\mu \mathrm{g} / \mathrm{ml}$ dengan jumlah sel $8,5 \times 10^{6} \mathrm{sel} / \mathrm{ml}$. Sedangkan pada perlakuan $2 \mathrm{x}$ pengenceran sisa gula reduksi pada jam ke-72 mencapai $164,4 \mu \mathrm{g} / \mathrm{ml}$ dengan jumlah sel 7,6 x $10^{6} \mathrm{sel} /$ ml. Gula reduksi yang dimanfaatkan $S$. cerevisiae untuk tumbuh kurang lebih $54 \%$ dari total gula reduksi awal yaitu 392,35 $\mu \mathrm{g} / \mathrm{ml}$. Penurunan gula reduksi ini menunjukkan bahwa kandungan dalam gula reduksi telah mampu mencukupi kebutuhan $S$. cerevisiae untuk tumbuh. Pertumbuhan yeast dipengaruhi oleh kandungan glukosa dalam substrat [19]. Penurunan kadar glukosa dalam substrat mempengaruhi metabolisme dalam sel sehingga menyebabkan kematian sel [14].

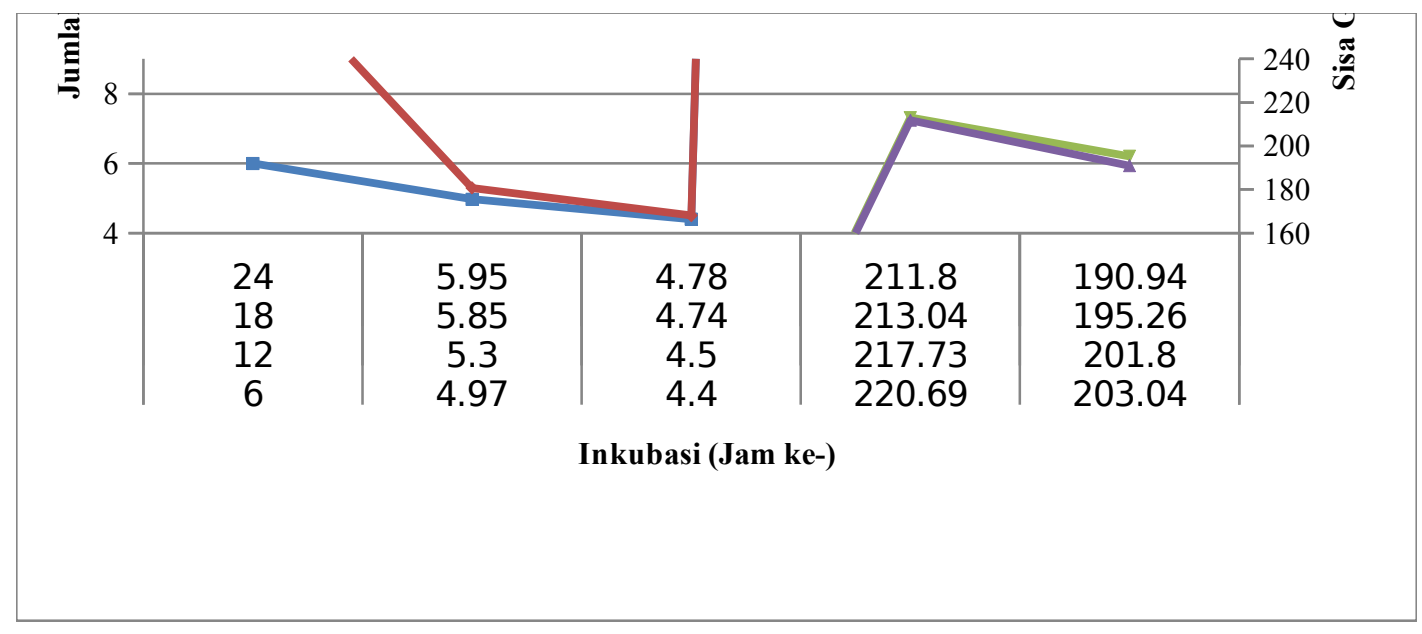

Gambar 2. Kurva Hubungan Populasi S. cerevisiae dan Konsumsi Gula Reduksi Keterangan: tanpa pengenceran $(\mathrm{sel} / \mathrm{ml})$; pengenceran $2 \mathrm{x}(\mathrm{sel} / \mathrm{ml})$;

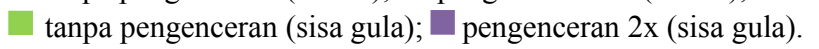

\section{KESIMPULAN}

Pertumbuhan $S$. cerevisiae mencapai $8,5 \times 10^{6}$ $\mathrm{sel} / \mathrm{ml}$ pada waktu inkubasi jam ke- 54 dan pada konsentrasi tanpa penegenceran. Seiring pertumbuhan $S$. cerevisiae, gula reduksi mengalami penurunan hingga jam terkahir inkubasi yaitu 180,44 $\mu \mathrm{g} / \mathrm{ml}$. Gula reduksi yang dimanfaatkan $S$. cerevisiae untuk tumbuh kurang lebih $54 \%$ dari total gula reduksi awal yaitu $392,35 \mu \mathrm{g} / \mathrm{ml}$.

Saran dari hasil penelitian ini adalah untuk dilakukan analisis hidrolisat setelah dilakukan produksi enzim . Sehingga saat produksi enzim skala besar dapat dilakukan tahapan tertentu untuk menyesuaikan kondisi lingkungan optimum untuk pertumbuhan $S$. cerevisiae. Selain itu, dapat dilakukan penambahan senyawa tertentu yang dapat mendukung pertumbuhan $S$. cerevisiae seperti nitrogen, fosfor, dan lain- lain.

\section{DAFTAR PUSTAKA}

[1] Amini, Rasoul S. 2011. Single Cell Protein: Production and Process,(May2014). https://doi.org/10.3923/ajft.2011.103.116.
[2] Anjarsari, B., \& Effendi, S. 2005. Pembuatan Protein Sel Tunggal dari Limbah Cair Pulp Kakao Oleh Saccharomyces cerevisiae. Jurnal Infomatek, 7(2), 93-105.

[3] Arroyo López F. N, Sandi Orlić, Amparo Querol, Eladio Barrio. 2009. Effects of temperature, $\mathrm{pH}$ and sugar concentration on the growth parameters of Saccharomyces cerevisiae, S. kudriavzevii and their interspecific hybrid. International Journal of Food Microbiology. 131, 120-127.

[4] Chubey B.B and Dorrell D. C. 1977. Total Reducing Sugar, Fructose And Glucose Concentrations And Root Yield Of Two Chicory Cultivars As Affected By Irrigation, Fertilizer And Harvest Dates. can. J. plant Sci. 5g: 7g9-793.

[5] Ernawati, \& Raudah. 2012. Pemanfaatan Kulit Kopi Arabika dari Proses Pulping untuk Pembuatan Bioetanol. Journal of Science and Technology, 10(21), 12-21.

[6] Guava, O. F., Canker, S., \& Governorate, I. N. E. 2015. Available Online at ESci Journals, 04(03), 121-136.

[7] Held P.Monitoring growth of beer brewing strains of Saccharomyces cerevisiae. Applicatio 
Note,Monitoring of Cell Suspensions by Kinetic

Absorbance Measurements, 2010.

[8] Hermiati, E., Mangunwidjaja, D., Sunarti, T.C., Suparno, O., \& Prasetyo, B. 2010. Pemanfaatn Biomassa Lignusellulosa Ampas Tebu untuk Produksi Bioetanol. Jurnal Litbang Pertanian, 29(4), $121-130$

[9] Khusna, D. ' J. S. 2015. Pemanfaatan Limbah Padat Kopi Sebagai Bahan Bakar Alternatif Dalam Bentuk Bricket Berbasis Biomass. Seminar Nasional Sains Dan Teknologi Terapan III, 247-260.

[10] Mandels M, Andreotti R \& Roche C. Measurement ofsaccharifying cellulase. Biotechnol. Bioeng. Symp. 6:21-33. 1976.

[11] Miranti, A. K., Rukmi, I., \& Suprihadi, A. 2009. Keanekaragaman Kapang Aspergillus pada Serasah Daun Talok ( Muntingia calabura L .) di Kawasan Desa Sukolilo Barat , Kecamatan Labang , Kabupaten Bangkalan, Madura The Diversity of Aspergillus Mold in Talok Leaf Litter ( Muntingia calabura L .) in West S, 98104

[12] Pelczar, Michael J. ECS. Chan. 2008. DasarDasar Mikrobiologi. Jakarta. UI Press.

[13] Penaloza WM, Molina MR, Brenes RG, Bressani R. 1985. Solid Substrate Fermentation: an Alternative to Improve the Nutritive Value of Coffee Pulp. Applied and Environmental Microbiology 49 : 388-393.

[14] Petrik M, Kappeli O, Fiechter A. 1982. An expanded concept for the glucose effect in the yeast Saccharomyces uvarum: Involvement of short and long-term regulation. Journal of General Microbiology. 129: 43-49.

[15] Pujiyanto. 2007. Pemanfaatan Kulit Buah Kopi dan Bahan Mineral Sebagai Amelioran Tanah Alami. Pelita Perkebunan, 23(2)(90), 159-172.
[16] Saraswati, R., \& Sumarno. 2008. Pemanfaatan Mikroba Penyubur Tanah sebagai Komponen Teknologi Pertanian. Iptek Tanaman Pangan, 3, 41-58. Retrievedfrom.

[17] Sena, A. R. De, Rodrigues, M., Mello, F. De, Cley, T., Leite, C., Moreira, K. A., \& Assis, S. A. De. 2014. Production, Characterization and Application of a Thermostable Tannase from Pestalotiopsis guepinii URM 7114, 52(4), 459467.

[18] Solehah, S.H. 2017. Hidrolisis Tandan Kosong Kelapa Sawit Oleh Trichoderma viridae dan Pestalotiopsis sp. (VM 9) Sebagai Media Pertumbuhan Protein Sel Tunggal Saccharomyces cerevisiae. Jurnal Skripsi. Vol (1)

[19] Vieira, É. D., Stupiello, G., \& Andrietta, S. R. 2013. Yeast biomass production : a new approach in glucose-limited feeding strategy, 558, 551558.

[20] Yuniar, W. 2013. Skrining dan Identifikasi Kapang Selulolitik pada Proses Vermikomposting Tandan Kosong Kelapa Sawit (TKKS). Jurnal skripsi (Vol. 1).

[21] Zhang, P. 2006. Involvement of Lignocellulolytic Enzymes in the Decomposition of Leaf Litter in a Subtropical Forest, 53(3), 193-198. https://doi.org/10.1111/j.1550-7408.2006.00093.x 